\title{
IDENTIFICATION OF CAUSAL DISEASE AGENT(S) OF CHERRY BACTERIAL CANKER IN MARMARA REGION OF TURKEY
}

\author{
Cansu Oksel ${ }^{1, *}$, Mustafa Mirik ${ }^{1}$ \\ ${ }^{1}$ Tekirdag Namık Kemal University, Department of Plant Protection, Tekirdag, Turkey
}

Current Trends in

Natural Sciences

\begin{abstract}
Bacterial cancer diseases of cherry (Prunus avium L) caused by Pseudomonas syringae (P. syringae) is one of significant diseases in fruit producing areas of the World and can cause major economics losses. So, the survey study was conducted to obtain the P. syringae pathovar(s) in Marmara Region of Turkey. Tress with symptoms of bacterial canker were found in six cities of nine cities visited and ninety-five of hundred-seven orchards between 2016 to 2018 years in Marmara Region. Gram negative bacterial isolates were isolated from margin of necrotic tissue. All isolates were based on pathogenicity, LOPAT, and GATTa tests, 63 isolates were identified as P. s. pv. syringae (Pss). For molecular study, showed that all isolates produced on approximately $752 \mathrm{bp}$ DNA fragment in PCR performed with primer set syrB1-syrB2. However, the results of MALDI- TOF MS analysis, the isolates were identified as Pss. According to the obtained results, it was concluded that Pss cause necrosis of cherry trees and its prevalence rate was determined as $58.88 \%$ in Marmara Region of Turkey.
\end{abstract}

Keywords: Bacterial canker, cherry, GATTa, MALDI-TOF MS, prevalence rate

\section{INTRODUCTION}

The production of cherries has increased in the last decade in the world. According to data from the Food and Agricultural organization for the 2014-2019 period, the average production of cherries increased from 2.187.770 to 2.595.812 tons. In Turkey, the average production of cherries is around 6 million tons in 2019. So, Turkey takes first place in producing cherries in the World (FA0, 2019) However, the bacterial canker has long been a problem in the production of sweet cherries worldwide. Bacterial canker is caused by P. syringae pv. syringae (Pss) and morsprunorum (Psm), and is an important disease of sweet cherry. Disease symptoms include blossom blast and spur dieback, leaf and fruit lesions, cankers with associated gummosis of woody tissue, loss of scaffold limbs, and overall decreased fruit yields (Kennelly et al., 2007; Spott et al., 2010).

Both phenotypic (including pathogenicity tests) and genetic methods are used for $P$. syringae identification. The pathogenicity test, in many cases even avirulent isolates can be allocated to the correct pathovar using the appropriate identification test (Young et al., 1992). Multiple tests on many different hosts are necessary to accurately determine the pathogenicity and host range of a $\mathrm{P}$. syringae isolate (Gilbert et al., 2009). The different pathovars and races of $P$. syringae isolate from cherry have been distinguished and characterized by physiological and biochemical tests (Burkowicz \& Rudolph, 1994; Garrett et al., 1966; Luz, 1997; Vicente et al., 2004) including the 
LOPAT (levan production, oxidase activity, pectolytic activity, arginine dihydrolase, hypersensitive reaction on tobacco) and GATTa tests (gelatin liquefaction (G), aesculin hydrolysis (A), tyrosinase activity (T) and tartrate utilization (Ta). (Lelliot et al., 1966; Latorre \& Jones, 1979; Vicente et al., 2004). Especially, GATTa tests are specifically useful for discrimination Pss and Psm (Latorre and Jones, 1979). However, The phytotoxin coronatine produced by $P s m$ isolates and syringomycin produced by Pss. So, PCR assay is used to identify by primers based on coronatine and syringomycin gene (Bereswill et al., 1994; Sorensen et al., 1998; Bultreys and Gheysen, 1999; Bultreys et al., 2006).

This study aimed to determine the causal agent(s) in the Marmara region of Turkey and characterized by biochemical, pathogenicity, molecular tests, and MALDI-TOF MS.

\section{MATERIALS AND METHODS}

\section{Survey}

In 2016-2018 period, the survey studies were conducted in Balıkesir, Bursa, Canakkale, Edirne, Kirklareli, Kocaeli, Istanbul, Tekirdag and Yalova in Marmara region of Turkey. The samples were collected from infected sweet cherry trees.

\section{Isolation and Pathogenicity}

The tissue pieces from infected plant samples were surface-sterilized for $15 \mathrm{sec}$ in $70 \%$ ethanol and macerated in $1 \mathrm{ml}$ of phosphate buffer. The isolation was carried out of King's B agar (King et al., 1956). The plates were incubated for $2-3$ days at $25^{\circ} \mathrm{C}$.

Pathogenicity of the obtained isolates was tested by inoculation of bacterial suspension $\left(10^{8} \mathrm{cfu} / \mathrm{ml}\right)$ on immature sweet cherry fruits and bean pods using a medicinal syringe (Klement, 1990; Gavrilovic, 2006). The steril distilled water (SDW) and Naip-1 (Pss) isolate were used as a control in the study.

\section{Biochemical and Physiological Characterization}

The tests were carried out a formation of levan and activity of oxidase, pectolytic enzymes, arginine dihydrolase, and hypersensitive reaction on tobacco leaves (LOPAT tests), as well as gelatin and aesculin hydrolysis, tyrosinase production, and use of tartaric acid (GATTa tests) (Lelliott et al., 1996; Kaluzna et al., 2010).

\section{MALDI-TOF Mass Spectrometer}

This method is based on revealing of microorganisms protein profile with ionization of protein structure and these ionized mass pass through the electrical field. Profiles that were obtained from microorganisms compare with a database of system thus identification is made by this way. Ribosomal proteins are used in identification which is less affected by environmental conditions. For bacterial isolates identification, the raw spectra of the unknown bacteria were used for pattern matching against the reference spectra of the database. The results of the pattern-matching process were expressed as proposed by the manufacturer, with $\log$ (scores) values ranging from 0 (no similarity) to 3 (absolute identity) (Carolis et al., 2012; Ziegler et al., 2012; Uysal et al., 2019).

\section{Genetic analysis of $P$. syringae pathovar}

Total genomic DNA was prepared by De Boer and Ward (1995). Determination of the presence of genes coding for synthesis of the bacterial phytotoxins syringomycin and coronatine was carried out by PCR with $s y r B$ encoding synthesis of syringomycin with primers syrB1 (5'CTTTCCGTGGTCTTGATGA-3') and syrB2 (2 (5'TCGATTTTGCCGTGATGAGT-3'), and $c f l$ encoding coronatine synthesis with primers CFLF (5'-GGCGCTCCCTCGCACTT-3') and CFLR (5'-GGTATTGGCGGGGGTGC-3'), amplifying a 752 bp band for syrB and 650 bp band cfl 


\section{Current Trends in Natural Sciences}

Vol. 10, Issue 19, pp. 368-374, 2021

https://doi.org/10.47068/ctns.2021.v10i19.048

Current Trends in Natural Sciences (on-line)

were expected. The PCR amplification procedure used is described by Bereswill et al. (1994) and Abbasi et al. (2013). The PCR products were electrophoresed on 1\% TBE agarose gel.

\section{RESULTS AND DISCUSSIONS \\ Survey}

The pathogen is known as a major problem in fruit-producing areas worldwide (Kennelly et al., 2007). Recently the cases of bacterial canker increased and pathogen became more prevalent (Spott et al., 2010). According to the study, a total of one hundred seven cherry orchards were surveyed in the Marmara region of Turkey. In Edirne, Kocaeli, and Yalova were not obtained infected plant samples. Also, our results indicated the prevalence of bacterial canker disease is $58.88 \%$ in the Marmara region of Turkey (Table 1).

Table 1. Survey study in Marmara region of Turkey

\begin{tabular}{|c|c|c|c|c|}
\hline \multirow{2}{*}{ Location } & \multicolumn{3}{|c|}{ Number of isolates } & $\begin{array}{c}\text { Number of } \\
\text { orchards }\end{array}$ \\
\cline { 2 - 5 } & 2016 & 2017 & 2018 & 11 \\
\hline Balıkesir & - & 5 & - & 8 \\
\hline Bursa & - & 3 & 5 & 12 \\
\hline Canakkale & 2 & 6 & 4 & 3 \\
\hline Edirne & - & - & - & 5 \\
\hline Kirklareli & - & 4 & - & 5 \\
\hline Kocaeli & - & - & 2 & 54 \\
\hline Istanbul & - & - & 13 & 3 \\
\hline Tekirdag & 2 & - & - & 5 \\
\hline Yalova & - & 17 & - & \\
\hline
\end{tabular}

\section{Isolation and Pathogenicity Test}

After isolation, the bacterial colonies that were white and fluorescent on King's B medium were selected and purified. A total of eighty-two bacterial isolates were obtained from sweet cherry orchards. 63 isolates were pathogenic to both sweet cherry fruits and bean pods inducing dark brown and sunken lesions of variable size 7- 10 days after inoculation (Moragrega et al., 2003). Reference Pss Naip1, used as a positive control in the pathogenicity test, also caused the same symptoms, while no symptoms were observed on tissue inoculated with SDW (Table 2). Balaz et al. (2016) indicated that Pss isolates from the sweet cherry in Serbia were showed the same pathogenicity result on immature cherry fruits. The symptoms were described that large, dark, and sunken spots (Gasic et al., 2012; Bulbul et al., 2015; Balaz et al., 2016).

\section{Biochemical and Physiological Characterization}

Sixty-three isolates were Gram(-) and produced fluorescent pigment on King's B medium like reported by Lelliott and Stead (1987). All isolates produced levan on SNA (Sucrose Nutrient Agar) medium and also water-soaked and necrotic lesions on tobacco leaves. Therefore, they belonged to the Pseudomonas group 1a. The GATTa tests are known differentiation within the $P$. syringae species. Pss isolates are hydrolyzed gelatin and aesculin (Schaad et al., 2001; Gilbert et al., 2009). The results of GATTa tests, sixty-three isolates showed the ability to gelatine liquefaction and aesculin hydrolysis. So, all isolates were identified as Pss (Table 2).

A previous study indicated that biochemical tests, though useful for the identification of bacterial genera and species, are often not discriminatory enough to determine P. syringae pathovars (Morris et al. 2000). 


\section{Current Trends in Natural Sciences}

Vol. 10, Issue 19, pp. 368-374, 2021

https://doi.org/10.47068/ctns.2021.v10i19.048

Current Trends in Natural Sciences (on-line)

ISSN: 2284-953X

Current Trends in Natural Sciences (CD-Rom)

ISSN: 2284-9521

ISSN-L: 2284-9521

ISSN-L: 2284-9521

\section{MALDI-TOF Mass Spectrometer}

The $\log$ (score) values of isolates were measured higher than 2.0. Also, the isolates were showed pattern-matching with reference in the database as Pss.

\section{Genetic analysis of $P$. syringae pathovar}

Pathovars of $P$. syringae, associated with stone fruits, produced several well-characterized phytotoxic compounds that can be used for pathovar differentiation. Like syringomycin is the main virulence factor for Pss. The syringomycin is developed necrotic tissues on cherry. So, Pss is distinguished from Psm. Detection of the $s y r B$ gene was routinely used for the determination of Pss (Gilbert et al., 2009; Kaluzna et al., 2010; Popovic et al., 2021). Detection of syrB gene, PCR amplification with primer syrB1 and syrB2 was produced 752 bp band on agarose gel-like as reference Pss isolate Naip1. However, PCR amplification with primer CFLF and CFLR was not observed 650 bp band size. So, the isolates were identified as Pss (Table 2).

Table 2. Determination of $P$. syringae isolates from cherry

\begin{tabular}{|c|c|c|c|c|c|c|c|c|c|}
\hline \multirow[t]{2}{*}{ Isolate } & \multirow[t]{2}{*}{ Locality } & \multirow{2}{*}{$\begin{array}{l}\text { Years of } \\
\text { isolation }\end{array}$} & \multirow{2}{*}{$\begin{array}{c}\text { Gram } \\
\text { reaction }\end{array}$} & \multirow[t]{2}{*}{ LOPAT } & \multirow[t]{2}{*}{ GATTa } & \multirow[t]{2}{*}{ Pathogenicity } & \multicolumn{2}{|c|}{ PCR } & \multirow[t]{2}{*}{ Result } \\
\hline & & & & & & & syrB & $c f l$ & \\
\hline TK1 & \multirow[t]{32}{*}{ Tekirdag } & 2018 & $\operatorname{Gram}(-)$ & +---+ & ++-- & + & + & - & $P s S$ \\
\hline TK2 & & 2018 & $\operatorname{Gram}(-)$ & +---+ & ++-- & + & + & - & $P s s$ \\
\hline TK3 & & 2018 & $\operatorname{Gram}(-)$ & +---+ & ++-- & + & + & - & Pss \\
\hline TK4 & & 2018 & $\operatorname{Gram}(-)$ & +---+ & ++-- & + & + & - & Pss \\
\hline TK5 & & 2018 & $\operatorname{Gram}(-)$ & +---+ & ++-- & + & + & - & $P s s$ \\
\hline TK6 & & 2018 & Gram(-) & +---+ & ++-- & + & + & - & $P s s$ \\
\hline TK7 & & 2017 & $\operatorname{Gram}(-)$ & +---+ & ++-- & + & + & - & Pss \\
\hline TK8 & & 2017 & $\operatorname{Gram}(-)$ & +---+ & ++-- & + & + & - & $P s s$ \\
\hline TK12 & & 2017 & Gram(-) & +---+ & ++-- & + & + & - & $P s s$ \\
\hline TK13 & & 2017 & $\operatorname{Gram}(-)$ & +---+ & ++-- & + & + & - & Pss \\
\hline TK17 & & 2017 & $\operatorname{Gram}(-)$ & +---+ & ++-- & + & + & - & $P s s$ \\
\hline TK18 & & 2017 & $\operatorname{Gram}(-)$ & +---+ & ++-- & + & + & - & Pss \\
\hline TK19 & & 2017 & Gram(-) & +---+ & +++- & + & + & - & Pss \\
\hline TK20 & & 2017 & $\operatorname{Gram}(-)$ & +---+ & ++-- & + & + & - & $P s s$ \\
\hline TK21 & & 2017 & $\operatorname{Gram}(-)$ & +---+ & ++-- & + & + & - & Pss \\
\hline TK24 & & 2017 & $\operatorname{Gram}(-)$ & +---+ & ++-- & + & + & - & $P s s$ \\
\hline TK25 & & 2017 & $\operatorname{Gram}(-)$ & +---+ & ++-- & + & + & - & Pss \\
\hline TK26 & & 2017 & $\operatorname{Gram}(-)$ & +---+ & ++-- & + & + & - & $P s s$ \\
\hline TK27 & & 2017 & $\operatorname{Gram}(-)$ & +---+ & ++-- & + & + & - & Pss \\
\hline TK28 & & 2017 & $\operatorname{Gram}(-)$ & +---+ & +++- & + & + & - & Pss \\
\hline TK29 & & 2017 & $\operatorname{Gram}(-)$ & +---+ & ++-- & + & + & - & $P s s$ \\
\hline TK30 & & 2017 & $\operatorname{Gram}(-)$ & +---+ & ++-- & + & + & - & $P s s$ \\
\hline TK31 & & 2017 & $\operatorname{Gram}(-)$ & +---+ & ++-- & + & + & - & $P s s$ \\
\hline TK33 & & 2018 & $\operatorname{Gram}(-)$ & +---+ & ++-- & + & + & - & Pss \\
\hline TK34 & & 2018 & $\operatorname{Gram}(-)$ & +---+ & ++-- & + & + & - & $P S s$ \\
\hline TK36 & & 2018 & $\operatorname{Gram}(-)$ & +---+ & ++-- & + & + & - & $P s s$ \\
\hline TK37 & & 2018 & $\operatorname{Gram}(-)$ & +---+ & ++-- & + & + & - & $P S S$ \\
\hline TK38 & & 2018 & Gram(-) & +---+ & ++-- & + & + & - & $P s s$ \\
\hline TK40 & & 2016 & $\operatorname{Gram}(-)$ & +---+ & ++-- & + & + & - & $P s s$ \\
\hline TK41 & & 2016 & $\operatorname{Gram}(-)$ & +---+ & ++-- & + & + & - & $P s s$ \\
\hline TK42 & & 2018 & $\operatorname{Gram}(-)$ & +---+ & ++-- & + & + & - & $P s s$ \\
\hline TK44 & & 2018 & $\operatorname{Gram}(-)$ & +---+ & ++-- & + & + & - & $P s s$ \\
\hline
\end{tabular}




\section{Current Trends in Natural Sciences}

Vol. 10, Issue 19, pp. 368-374, 2021

https://doi.org/10.47068/ctns.2021.v10i19.048

Current Trends in Natural Sciences (on-line)

\begin{tabular}{|c|c|c|c|c|c|c|c|c|c|}
\hline $\mathrm{BaK} 2$ & \multirow[t]{5}{*}{ Balıkesir } & 2017 & Gram(-) & +---+ & ++-- & + & + & - & $P s s$ \\
\hline BaK3 & & 2017 & Gram(-) & +---+ & ++-- & + & + & - & Pss \\
\hline $\mathrm{BaK} 4$ & & 2017 & $\operatorname{Gram}(-)$ & +---+ & ++-- & + & + & - & $P s s$ \\
\hline $\mathrm{BaK} 7$ & & 2017 & Gram(-) & +---+ & ++-- & + & + & - & $P s s$ \\
\hline $\mathrm{BaK} 8$ & & 2017 & Gram(-) & +---+ & ++-- & + & + & - & $P s s$ \\
\hline BuK1 & \multirow{8}{*}{ Bursa } & 2017 & $\operatorname{Gram}(-)$ & +---+ & ++-- & + & + & - & $P s s$ \\
\hline BuK2 & & 2017 & Gram(-) & +---+ & ++-- & + & + & - & $P s s$ \\
\hline BuK3 & & 2017 & Gram(-) & +---+ & ++-- & + & + & - & $P s s$ \\
\hline BuK6 & & 2018 & $\operatorname{Gram}(-)$ & +---+ & ++-- & + & + & - & $P S S$ \\
\hline BuK7 & & 2018 & Gram(-) & +---+ & ++-- & + & + & - & $P S S$ \\
\hline BuK8 & & 2018 & Gram(-) & +---+ & ++-- & + & + & - & $P s s$ \\
\hline BuK9 & & 2018 & $\operatorname{Gram}(-)$ & +---+ & ++-- & + & + & - & $P S S$ \\
\hline BuK10 & & 2018 & Gram(-) & +---+ & ++-- & + & + & - & $P s S$ \\
\hline ÇK1 & \multirow[t]{12}{*}{ Çanakkale } & 2016 & Gram(-) & +---+ & ++-- & + & + & - & Pss \\
\hline ÇK2 & & 2016 & $\operatorname{Gram}(-)$ & +---+ & ++-- & + & + & - & $P S s$ \\
\hline ÇK4 & & 2017 & Gram(-) & +---+ & ++-- & + & + & - & $P S S$ \\
\hline ÇK5 & & 2017 & Gram(-) & +---+ & ++-- & + & + & - & $P S S$ \\
\hline ÇK6 & & 2017 & $\operatorname{Gram}(-)$ & +---+ & ++-- & + & + & - & $P S s$ \\
\hline ÇK7 & & 2017 & $\operatorname{Gram}(-)$ & +---+ & ++-- & + & + & - & $P s S$ \\
\hline ÇK8 & & 2017 & $\operatorname{Gram}(-)$ & +---+ & ++-- & + & + & - & $P s S$ \\
\hline ÇK9 & & 2017 & Gram(-) & +---+ & ++-- & + & + & - & $P s s$ \\
\hline ÇK10 & & 2018 & $\operatorname{Gram}(-)$ & +---+ & ++-- & + & + & - & $P s s$ \\
\hline ÇK11 & & 2018 & $\operatorname{Gram}(-)$ & +---+ & ++-- & + & + & - & $P s s$ \\
\hline ÇK12 & & 2018 & Gram(-) & +---+ & ++-- & + & + & - & $P s S$ \\
\hline ÇK13 & & 2018 & $\operatorname{Gram}(-)$ & +---+ & ++-- & + & + & - & $P s s$ \\
\hline KK1 & \multirow[t]{4}{*}{ Kırklareli } & 2017 & $\operatorname{Gram}(-)$ & +---+ & ++-- & + & + & - & Pss \\
\hline KK2 & & 2017 & $\operatorname{Gram}(-)$ & +---+ & ++-- & + & + & - & $P s S$ \\
\hline KK3 & & 2017 & $\operatorname{Gram}(-)$ & +---+ & ++-- & + & + & - & Pss \\
\hline KK4 & & 2017 & $\operatorname{Gram}(-)$ & +---+ & ++-- & + & + & - & $P S S$ \\
\hline IsK1 & \multirow[t]{2}{*}{ İstanbul } & 2018 & $\operatorname{Gram}(-)$ & +---+ & ++-- & + & + & - & $P S S$ \\
\hline IsK2 & & 2018 & Gram(-) & +---+ & ++-- & + & + & - & Pss \\
\hline $\begin{array}{l}\text { Naip1 } \\
\text { (ref. } P s s \text { ) }\end{array}$ & Tekirdağ & 2014 & $\operatorname{Gram}(-)$ & +---+ & ++-- & + & + & - & Pss \\
\hline
\end{tabular}

\section{CONCLUSIONS}

In the survey, studies were conducted nine different cities in Marmara region of Turkey. However, six cities out of nine were obtained the bacterial canker. The result of this study indicated that bacterial canker is present and spread in cherry orchards in the Marmara region of Turkey. Characterization of the isolates indicated that Pss is caused by bacterial canker in cherry orchards in the Marmara region. All tests were supported the Pss. it was concluded that Pss cause necrosis of cherry trees and its prevalence rate was determined as 58.88\% in Marmara Region of Turkey.

\section{ACKNOWLEDGEMENTS}

This study was a part of the Ph.D. thesis namely Identification, genotypic characterization of causal agent of cherry bacterial canker in marmara region, and determination of susceptibility against different compound.

\section{REFERENCES}

Abbasi, V., Rahminian, H., Ghanbari, M. A. T. (2013). Genetic variability of Iranian strains of Pseudomonas syringae causing bacreial canker disease on stone fruits. Eur J Plant Pathol, 135, 225-235. 


\section{Current Trends in Natural Sciences}

Vol. 10, Issue 19, pp. 368-374, 2021

https://doi.org/10.47068/ctns.2021.v10i19.048

Current Trends in Natural Sciences (on-line)

ISSN: 2284-953X

Current Trends in Natural Sciences (CD-Rom)

ISSN: 2284-9521

ISSN-L: 2284-9521

ISSN-L: 2284-9521

Balaz, J., Ilicic, R., Ognjanov, V., Ivanovic, Z., Popovic, T. (2016). Etiology of bacterial canker on young sweet cherry trees in Serbia. Journal of Plant Pathology, 98(2),285-294.

Bereswill, S., Bugert, P., Völksch, B., Ullrich, M., Bender, C. L., Geider, K. (1994). Identification and relatedness of coronatine-producing Pseudomonas syringae pathovars by PCR analysis and sequence determination of amplification products. Applied and Environmental Microbiology, 2924-2930.

Bultreys, A., Gheysen, I. (1999). Biological and molecular detec- tion of toxic lipodepsipeptide-producing Pseudomonas syringae strains and PCR identification in plants. Applied and Environmental Microbiology, 65, 1904-19.

Bultreys, A., Gheysen, I., Hoffmann, de E. (2006). Yersini- abactin production by Pseudomonas syringae and Escherichia coli and description of a second yersiniab actin lo- cus evolutionary group. Applied and Environmental Micro- biology, 72, 3814-38.

Burkowicz, A., Rudolph, K. (1994). Evaluation of pathogenicity and of cultural and biochemical tests for identification of Pseudomonas syringae pathovars syringae, morsprunorum and persicae from fruit trees. Journal of Phytopathology, 141, 59-76.

Bulbul, M., Mirik, M. (2015). Prevalence, isolation and identification of bacterial canker pathogens on sweet cherry trees in Tekirdag. Journal of Turkish Phytopathology, 43,15-24.

Carolis, E.D., Posteraro, B., Lass-Flo, C., Vella, A., Florio, A. R., Torelli, R., Girmenia, C., Colozza, C., Tortorano, A.M., Sanguinetti M., Fadda, G. (2012). Species identification of Aspergillus, Fusariumand Mucoraleswith direct surface analysis by matrix-assisted laser desorption ionization time-of-flight mass spectrometry. Clinic Microbiology Infect., 18, 475-484.

FAO, 2019. www.faostat.fao.org. 29\02\2021.

Gašić K., Prokić A., Ivanović M., Kuzmanović N., Obradović A. (2012). Differentiation of Pseudomonas syringae pathovars originating from stone fruits. Pesticides and Phytomedicine, 27 (3), 219-229.

Garrett, C.M.E., Panagopoulos, C.G., Crosse, J.E. (1966). Comparison of plant pathogenic pseudomonads from fruit trees. Journal of Applied Bacteriology, 29, 342-3.

Gavrilović, V. (2006). Patogene i biohemijsko fiziološke karakteristike bakterija roda Pseudomonas parazita voćaka [Pathogenic and biochemical-physiological characteristics of the bacteria from genus Pseudomonas the pathogen of fruit trees]. Zaštita bilja, 255-258, 5-55.

Gilbert, V., Legros, F., Maraite, H. ve Bultreys, A. (2009). Genetic analysis of Pseudomonas syringae from Belgian fruit orchards reveal genetic variability and isolate-host relationships within the pathovar syringae, and help idetify both races of the pathovar morsprunorum. Eur J Plant Pathol, 124, 199-218.

Kaluzna, M., Ferrante, P., Sobiczewski, P., Scortichini, M. (2010). Characterization and genetic diversity of Pseudomonas syringae from stone fruits and hazelnut using repetiyive-PCR and MLST. Journal of Plant Pathology, 92(3), 781-787.

Kennelly, M .M., Cazorla, F. M., Vicente, A., Ramos, C. ve Sundin, G. W. (2007). Pseudomonas syringae diseases of fruit trees progress toward understanding and control. Plant Disease, 91,1.

Lattore, B. A., Jones, A. L. (1979). Pseudomonas morsprunorum, the cause of bacterial canker sour cherry in Michigan, and its epiphytic association with P. syringae. Phytopathology, 69, 335-339.

Lelliott , R. A., Billing, E., Hayward, A. C. (1966). A determinative cheme for the fluorescent plant pathogenic pseudomonads. Journal of Applied Bacteriology, 29, 470-489.

Lelliott R.A., Stead D.E. (1987). Methods for Diagnosis of Bacterial Diseases of Plants. Blackwell Scientific Publications, Oxford, UK.

Luz J.P.M. (1997). Detection and epidemiology of bacterial canker (Pseudomonas syringae) on wild cherry (Prunus avium). PhD Thesis.

Moragrega C, Llorente I., Manceau C, Montesinos E. (2003). Susceptibility of European pear cultivars to Pseudomonas syringae pv. syringae using immature fruit and detached leaf. European Journal of Plant Pathology, 109,319326.

Morris, C.E., Glaux, C., Latour, X., Gardan, L., Samson, R., Pitrat, M. (2000). The relationship of host range, physiology, and genotype to virulence on cantaloupe in Pseudomonas syringae from cantaloupe blight epidemics in France. Phytopathology, 90, 636-646.

Popovic T., Menkovic J., Prokic A., Zlatkovic N., Obradovic A. (2021). Isolation and characterization of Pseudomonas syringae isolates afecting stone fruits and almond in Montenegro. Journal of Plant Diseases and Protection, $128,391-405$ 


\section{Current Trends in Natural Sciences}

Vol. 10, Issue 19, pp. 368-374, 2021

https://doi.org/10.47068/ctns.2021.v10i19.048

Current Trends in Natural Sciences (on-line)

ISSN: 2284-953X

Current Trends in Natural Sciences (CD-Rom)

ISSN: 2284-9521

ISSN-L: 2284-9521

ISSN-L: 2284-9521

Schaad, N. W., Jones, J. B., Chun, W. (2001). Laboratory Guide for Identification of Plant Pathogenic Bacteria. The American Phytopathological Society, St. Paul, MN., USA.

Sorensen, K.N., Kim, K.H., Takemoto, J.Y. (1998). PCR detection of cyclic lipodepsinonapeptide-producing Pseudomonas syringae pv. syringae and similarity of strains. Applied and Environmental Microbiology, 64 (1), 226-230.

Spotts, R. A., Wallis, K. M., Serdani, M., Azarenko, A. N. (2010). Bacterial canker of sweet cherry in Oregon-infection of horticultural and natural wounds and resistance of cultivar and rootstock combination. Plant Disease, 93, 345350.

Uysal, A., Kurt, Ş., Soylu, S., Soylu, E. M., Kara, M. (2019). Identification of microorganism species in leafy vegatables using MALDI-TOF MS tecnique. YYU Journal of Agricultural Science, 29(4),595-602.

Vicente, J. G., Alves, J. P., Russell, K., Roberts, S. J. (2004). Identification and discrimination of Pseudomonas syringae isolates from wild cherry in England. European Journal of Plant Pathology, 110(4), 337-351.

Young, J.M., Takikawa, Y., Gardan, L., Stead D.E. (1992). Changing concepts in the taxonomy of plant pathogenic bacteria. Annual Review of Phytopathology, 30, 67-1 